\title{
TYROBP wt Allele
}

National Cancer Institute

\section{Source}

National Cancer Institute. TYROBP wt Allele. NCI Thesaurus. Code C52334.

Human TYROBP wild-type allele is located in the vicinity of $19 q 13.1$ and is approximately 4 $\mathrm{kb}$ in length. This allele, which encodes TYRO protein tyrosine kinase-binding protein, plays a role in the modulation of killer cell activation. Mutation of the gene is associated with polycystic lipomembranous osteodysplasia with sclerosing leukoencephalopathy. 